\title{
Poesía
}

\section{David 3.0}

\section{José Alcami Pertejo}

Profesor de Investigación del Centro Nacional de Microbiología, Instituto de Salud Carlos III; ppalcami@isciii.es

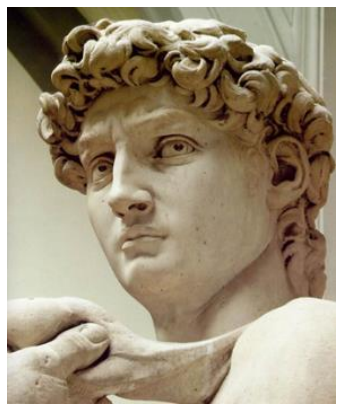

David, Miguel Ángel, Galería

de la Academia, Florencia, Italia

Frente al abismo del tiempo

David se yergue.

Contempla el gigante amenazador

y más allá el universo

y más acá su alma

Su mirada serena susurra

“Este es mi destino.

Si muero, no importa,

Si venzo, no importa.

Sólo importa el lugar que ocupo,

el instante que vivo,

la piedra en la honda

que lanzaré como un sueño.

Si muero, no importa,

si venzo, no importa,

mi destino,

la piedra en la honda,

... la eternidad,

la piedra que habito"

(C) 2018 por los autores; Esta obra está sujeta a la licencia de Reconocimiento 4.0

Internacional de Creative Commons. Para ver una copia de esta licencia, visite http://creativecommons.org/licenses/by-nc-nd/4.0/. 